\title{
Media and receiving country' language: the integration of Nepalese immigrants in Portugal
}

Branco I. (2018) Media and the Receiving Country's Language: The Integration of Nepalese Immigrants in Portugal. In: Karim K., AlRawi A. (eds) Diaspora and Media in Europe. Palgrave Macmillan, Cham. DOI: https://doi.org/10.1007/978-3-319-65448-5_7, Print ISBN978-3-319-65447-8, Online ISBN 978-3-319-65448-5

This chapter focuses on Nepalese immigrant community living in Portugal and on how immigrants use different media - from receiving country, homeland and global sources - to preserve the links with the home country in the process of integration into the new society. The study also analyses how the media (mainstream) of the country of settlement are used to learn its language (Portuguese).

Theoretically, the research is based on the model of uses and gratifications of media (Katz \& Blumler, 1974), on Berry's model of acculturation strategies (Berry, 2001) and on Bourdieu's theory of power and practice (Bourdieu, 1991), specifically in what concerns language as symbolic power. The methodology relied on 17 questionnaires and eight in-depth interviews. The results of the study show the importance that media have at different periods of immigrant s' lives, depending on the level of integration into the receiving society. In forming a new identity where values and customs of different cultures mix together, in adjusting to a new place of living and in maintaining connections to familial and cultural past, immigrants find in media tools that help them overcome some of the key barriers inherent to the migration process, in particular, the learning of the new country's language.

Keywords: Nepalese diaspora, immigration, media, language, identity, integration 


\section{Contextualizing Nepalese immigration in Portugal}

Portugal has gone through a change in the recent decades regarding its migration flows. Prior to the seventies, it was characterized as a country of emigration; from 1974 onwards, with the independence of its colonies (e.g. Mozambique, Angola, Cape Verde, San Tome and Principe, Guinea Bissau and East Timor) and the consequent arrival in Portugal of residents from those countries, the situation changed. At present, while remaining a country of emigrants, it has also become a country of immigrants. In the seventies and eighties, immigration consisted mainly of individuals from African Portuguese Speaking Countries (PALOP); the nineties had the predominance of immigrants from Eastern Europe and Brazil, and in the twenty-first century, Portugal began to receive immigrants from Asian countries such as China, India, Bangladesh, Pakistan and Nepal, currently the most significant among small immigrant communities.

Besides the geographical origin, those communities also have in common their socioeconomic integration based on family microenterprises and self-employment in catering, trade and services. These recent populations are concentrated in Lisbon and are formed mostly of adults of working age with some children and elderly people (Pires, Machado, Peixoto, \& Vaz, 2010, p. 60).

Table 1 shows the evolution of the largest communities of Asian origin, among a total of 46 , since 2006. As shown, from 2006 to 2011 the most numerous arrivals were from the same four countries (China, India, Pakistan, and Bangladesh). However, in 2012 the fourth largest community was no longer from Bangladesh; it became the Nepalese community, with 1,702 individuals (SEFSTAT, 2014). Of these, 1,094 were men and 608 were women. These data show that the trend in these communities goes against the current trend of decrease in the 
number of foreign residents in Portugal. It should be noted that these figures relate only to foreigners with residence permits.

Table 1. Evolution of the largest Asian communities in Portugal, 2006-2013

\begin{tabular}{|l|l|l|l|l|l|l|l|l|}
\hline & 2006 & 2007 & 2008 & 2009 & 2010 & 2011 & 2012 & 2013 \\
\hline CHINA & 10,167 & 10,448 & 13,331 & 14,396 & 15,699 & 16,785 & 17,447 & 18,637 \\
\hline INDIA & 3,785 & 4,104 & 5,519 & 5,782 & 5,271 & 5,384 & 5,657 & 6,022 \\
\hline PAKISTAN & 2,205 & 2,371 & 2,736 & 2,698 & 2,604 & 2,474 & 2,425 & 2,628 \\
\hline BANGLADESH & 1,090 & 1,180 & 1,577 & 1,346 & 1,007 & 1,149 & 1,351 & 1,733 \\
\hline NEPAL & 285 & 302 & 560 & 685 & 797 & 1,145 & 1,702 & 2,588 \\
\hline
\end{tabular}

Source: SEFSTAT, Statistics Portal of Portuguese Foreign Services (SEF)

\section{Identity, belonging and integration}

The idea of belonging is part of the notion we have of our own identity. The relationship between belonging and identity is important to understand the identity construction of an immigrant, the process of integration into the receiving society and the factors involved in both cases. In his book In the name of Identity: violence and the need to belong ${ }^{1}$, Amin Maalouf (1998, p. 9) highlights the dilemma of identity construction among immigrants. First, hybridity - belonging, at the same time, to the homeland culture and to the receiving culture - second, belonging to various social groups - the immigrant community and the wider receiving society group - third, the fact that each identity is unique and the different belongings make it unique.

There is a relationship between what the individual is as a human being and what he is as a reflection of the groups to which he belongs. There is continuity between these two forms of existence - individual and group. Social identity means the characteristics that others assign to an individual. Those characteristics can be seen as markers that indicate, in general, who that person is, and, at the same time, the person's position towards other individuals who

\footnotetext{
${ }^{1}$ English translation of the French original "Les identités meurtrières".
} 
share the same attributes. If social identities establish the ways in which individuals are similar to others, personal identity distinguishes them as individuals. This type of identity refers to the process of personal development through which the individual formulates an intrinsic sense of self and relationship with the world around him (Giddens, 2007, pp. 29-30). This relationship between belonging and identity poses two problems to the individual: on the one hand, the need to belong and, on the other, the need to assert himself/herself as belonging to something. If we understand this relationship, we understand the need of an immigrant to be seen as belonging to his/her society of origin, but also as belonging to the receiving society. The contact between the group to which the immigrant originally belongs and the cultural group where he or she lives at present requires a behavioural change from the members of the two groups, which Berry (2001, p. 617) denominates as acculturation.

Virtually all behaviours in the repertoire of a person are candidates for change after an engagement with other cultures. In most cases, there is a fairly easy transition, involving the abandonment of some of the elements of his or her home culture and the learning of some elements of another. Individuals can change the way they dress, what they eat, how they greet, even their values. The pace and extent of individual change are clearly related to the degree of cultural maintenance within their own group, which, in turn, is linked to his demographic, economic and political situation regarding other groups.

Berry (2001, p. 620) identifies two dimensions along which immigrants (re)construct their cultural identity. The first of these dimensions is identification with a heritage or cultural group, and the second is the identification with the dominant society. These two aspects of cultural identity are referred by the author as ethnic identity and civic identity.

Using these two dimensions of identity, the author defines four strategies of acculturation. The strategy of assimilation is defined when individuals do not wish to retain their cultural 
identity and only seek a daily interaction with other cultures. In contrast, the strategy of separation is chosen when individuals remain faithful to their native culture and at the same time wish to avoid interaction with other people in the receiving society.

When there is as much interest in maintaining their original culture as in daily interactions with other groups, integration is the option. In this case, immigrants maintain a certain degree of cultural integrity; while seeking, as members of a cultural group, to participate as part of the broader social network.

Finally, when there is little possibility or interest in cultural maintenance (often for reasons of enforced cultural loss), and little interest in having contact with others (often for reasons of exclusion or discrimination), it is marginalization that is chosen.

To sum up, when both identities - ethnic and civic - are affirmed, there is an integration strategy; when people do not feel connected to any of the two, there is a sense of marginalization; when one is heavily emphasized over the other, a strategy of assimilation or separation is revealed. Regarding the integration strategy, the greater the desire for interaction with the host society, the greater the degree of integration.

\section{Language and symbolic power}

The use of language and the proficiency of its speakers express power relations. Variations in accent, intonation and vocabulary reflect different positions in the social hierarchy.

Individuals speak with varying degrees of authority and the value of words depends on who speaks the words and how they are spoken. Words can be used as instruments of coercion, intimidation, but also sensitivity and condescension. Language is an integral part of social life, since much of it consists in a daily exchange of linguistic expressions. 
In the theory and practice approach used by Bourdieu (1991), he tries to clarify some issues related to language and its use. For him, the speakers of a language do not all have the same ability to speak it. The competence of individuals to speak a particular language is not limited to its ability to generate an unlimited sequence of grammatically correct sentences; it is also the ability to produce expressions that are appropriate to specific situations.

Competent speakers have a practical competence or a practical sense which makes them able to produce sentences appropriated to the circumstances, i.e., the phrases or expressions they produce are part of practical strategies that have numerous functions and are tacitly adjusted to power relations between those who speak and those who listen. Practical competence refers to the ability that speakers have to be heard, to be credible and even obeyed. Those who speak must ensure that they possess the necessary qualifications to do it in specific circumstances, and those who hear must recognize that the speaker deserves attention.

The key concept used by Bourdieu in his approach is that of habitus (Bourdieu, 1991, p. 12), which refers to a set of disposals that prepossesses agents to act or react in a certain way. Those disposals are acquired through a process of inculcation in which early childhood experiences are particularly important.

Through a variety of processes of training and learning the individual acquires a set of rules, such as the way of eating, sitting, etc., that literally shapes the body and become second nature. The habitus creates in the individual a practical sense of how to act and how to respond to several situations in the course of his/her life. But when individuals act, they do so in a specific social context. Certain practices and perceptions should be viewed not as a product of habitus, but as a product of the relationship between habitus and the specific social contexts or fields in which individuals act. A field or market can be seen as a structured space of positions in which practices and their inter-relationships are determined by the distribution of different types of resources or capital. 
Bourdieu emphasizes the importance of linguistic capital in the field or social context. Linguistic capital is a form of social capital, understood as the set of resources, actual or potential, which are linked to the possession of a durable network of institutionalized relationships of mutual knowledge and recognition. There are different forms of social capital, not just economic capital in its literal sense (money, cash), but also cultural capital (knowledge, academic skills) or symbolic capital (prestige, honour). One of the main characteristics of social contexts, or fields as Bourdieu calls them, is how they allow one form of capital be converted into another - for example, how a particular type of educational qualifications may be taken into account in finding a better job.

In the economic language of Bourdieu, language products have a certain value in a given linguistic market. Some products are more valuable than others and, therefore, part of the practical competence of speakers is to know how to produce (and having the ability to produce) expressions that are highly valued in these markets. Different speakers have different amounts of language capital, that is, different abilities to produce expressions for a particular market. The distribution of linguistic capital is also related to the distribution of other forms of capital which define the location of an individual in a social space. Differences in accent, grammar and vocabulary are indications of social status of speakers and reflect the amount of linguistic and other forms of capital that they possess.

By taking for granted certain aspects of hierarchical social structure, individuals from social classes that are disadvantaged in terms of cultural or economic capital share and accept an evaluation system that works against them. This is one example of what Bourdieu calls symbolic power or symbolic violence. Such power is transmuted into a symbolic form, and thus endowed with certain legitimacy. This is an invisible power in contrast to the physical power. It is an under-recognized power or violence and therefore recognized as legitimate. Because they don't recognize this form of power as violence against them, these individuals 
accept it instead of opposing it. One example related to immigrants is the access to language courses or to translators in public services. If immigrants just accept that they can't apply for certain jobs because they don't have enough knowledge of the language of the receiving country, they end up working for other members of their community, closed in their own system and with low level of integration into the wider society.

It should be noted that the use of the term class by Bourdieu differs from the traditional notion in Marxist literature. Bourdieu does not set the class on the basis of ownership of the means of production. For him, classes are a set of individuals who have similar functions in the social space, having similar opportunities in life. Class may relate to existing social division in contemporary societies, based for example on gender or ethnicity.

Immigrants or immigrant communities can be classified as classes and can be a target of the symbolic power between the society that dominates and the community that is subordinated. The issue is to identify how this power is exercised and how immigrant communities can resist it. What Bourdieu emphasizes is the importance of language as a form of resistance. When an immigrant learns the dominant language, he becomes more able to move within the receiving society, i.e., the higher his or her linguistic capital, the better the immigrant is able to exploit the system of differences to his/her own advantage, ensuring a capital of distinction (Bourdieu, 1991, p. 18).

\section{Media and immigration}

The media owned by minorities depends on several sources, production methods and schedules to generate content. This fact is related to the nature of media audiences, circumscribed to specific local or national spaces but connected to social networks across borders. These audiences seek information about their countries of origin, about the wider 
space of the diaspora to which they belong and about local or national contexts in which they live.

Immigrant communities maintain and, in part, depend on transnational media communication to share their sense of identity. The local and national contexts in which these communities live are equally important for the construction of the identity of those communities, especially because the experiences of inclusion, exclusion and participation in their host societies are based on these spaces. Thus, the audiences constituted by immigrant minorities divide their attention between their own media and the media of the majority.

Currently, studies on audiences researching about the reception and the identity of minorities fall mainly on ethnic or diasporic media. This tendency to explore the multidimensional effects of media used by immigrants began in the 1970s, while the assimilationist ideology began to be abandoned and replaced by the metaphor of "cultural mosaic", cultural pluralism or multiculturalism (Pareck, 2000, p.7; Berry \& Sam, 2006, p.28 and Giddens, 2007, p. 258). The focus of the investigations started to rely on the dual role of the home language media: on the one hand, in helping the integration into a new environment and, on the other hand, in the maintenance of pride and ethnic identity, intra-group solidarity and language and culture of origin (Elias, 2011).

What these media have in common is that they represent cultural, linguistic and religious groups who live within large and diverse multicultural societies. Their audiences, meanwhile, are located both in towns or cities and in countries or nation-states. Within the latter, they constitute themselves as minorities with an imagined or real link between them, and a shared sense of belonging to a larger community, spread beyond national borders, an "imagined community": 
"It is imagined because the members of even the smallest nation will never know most of their fellow-members, meet them, or even hear of them, yet in the minds of each lives the image of their communion" (Anderson, 1991, p. 25).

The research on media and ethnic minorities can be grouped in four categories: representation of ethnic minorities in mainstream media; ethnic minorities as mainstream media audiences; ethnic minorities as ethnic media audiences; and ethnic minorities as transnational media audiences.

\section{Representation of ethnic minorities in mainstream media}

This type of research brings out the feelings of underrepresentation of minorities on the national public space and the unpleasant image of minority groups in the mainstream media. Although minorities might contribute with contents to the mainstream media, such access is usually not sustained or consistent and, in most cases, minorities do not recognize themselves in the images produced by those media (Silverstone \& Georgiou, 2005). Minorities may become part of the content of the media of the majority, although in most cases they are not. Even so, when these minorities emerge or are represented in the media it is most often through stereotyped images.

\section{Ethnic minorities as active audiences in ethnic media}

Studies on migrant audiences in Europe are not immune to ideological assumptions that see them as potential perpetrators of identity differences. These studies choose predominantly diasporic media to research about the reception and the identity of minorities. Research is done from two perspectives. One perspective is the maintenance of links between the diaspora and the country of origin. Another perspective focuses on the integration in the host society and assesses whether the diasporic media reproduce cultural differences and ethnic identification. 
The first case highlights the role of ethnic media in strengthening the feeling of immigrants to take part in society while maintaining the uniqueness of the community to which they belong (Georgiou, 2005). In the second case, the ethnic media can both help immigrants feel at home in their destination countries, serving as means of learning about the new society and about the ways they can adapt to it; but they can also help slowing down the process of integration by promoting the closure of immigrants within their own community (Wood \& King, 2001).

\section{Ethnic minorities as active audiences of mainstream media}

This approach goes towards the studies on uses and gratifications of media (Katz \& Blumler, 1974). Compared to "traditional" reception studies, which are focused on the meanings that audiences attribute to media representations, research on uses and gratifications is focused on active audiences of media, social contexts of use, and on the motivations of the audience to consume certain media content (Livingstone, 2002; Reece \& Palmegreen, 2000).

In studies about minority audiences focused on mainstream or national media (Reece \& Palmgreen, 2001; Elias \& Lemish 2006, 2008, 2010, 2011) attention is given to the contexts which stress some specific reasons for using certain media for satisfaction of needs that become also more salient in these contexts. These studies have shown that these media provide immigrants with elements that enable them to understand the history of the host culture, values and existing social or economic problems, as well as to learn the host language.

\section{Ethnic minorities as active audiences of transnational media}

In the context of transnational or global media we can also make the distinction between mainstream and ethnic media. The difference is the transnational nature of these means, which include the Internet, satellite television and cable TV. Studies dedicated to the relationship between immigrant minorities and transnational media have highlighted two 
types of trajectories: one that emphasizes the role of these media in maintaining ties between diaspora communities and their countries of origin (Elias \& Lemish, 2006, 2008, 2010, 2011); and another that emphasizes the relevance of ICTs, especially the Internet, in the achievement of migratory aspirations, as it is used to explore the world, looking for opportunities, information, contacts and new ideas (Burrell \& Anderson, 2008).

\section{Methodological approach}

This research follows the line of studies about media and audiences that look at immigrants as active audiences with specific needs that result from a process of relocation, especially in the European context (Elias, 2011; Elias \& Lemish, 2006, 2008, 2010, 2011; Burrell \& Anderson, 2008). It assumes that, while media audiences, immigrants have their own motivations and seek to meet specific needs. Consequently, they are involved in the effects produced by the media. This research explores this perspective of the relationship between media and immigration and, by doing so, it adopts the perspective of the theory of uses and gratifications of media ( $U$ \& G).

According to Livingstone (1997), the theory of U \& G (Katz, Blumler \& Gurevich, 1974), is a contextualized approach to the effects of media and, as formulated initially, argued against a vision of a mass society, made up of homogeneous media and of helpless spectators audiences. On the contrary, by putting the emphasis on active audiences, in social contexts of the media uses and on the different motivations for using different media and different content, this theory has been the basis of ethnographic studies about audiences. With regard to context, studies on uses and gratifications of media meet the individual habits, not only the social and cultural structures. Regarding the effects of media, they assume that they result in 
the satisfaction or gratification of the needs of the audience and not in the mere acceptance of media messages to those audiences.

This research aims to understand the functions and uses of three types of media mainstream, ethnic and transnational - in the identity construction of immigrants, which take place in the threshold between their country of origin, the receiving country and their connections with the rest of the world.

Based on the theoretical model of uses and gratifications of media (Katz \& Blumler, 1974), the methodology used in the research relied on 17 questionnaires and 8 in-depth interviews. First, we applied the questionnaires to a class of Nepalese immigrants who were learning Portuguese at Non-resident Nepalese Association (NRN), in Lisbon. The questionnaire aimed to understand the reasons to choose Portugal as the receiving country; which languages do Nepalese immigrants speak; motivations to learn Portuguese; and how they learn the language (where the use of media was an option). From the 17 respondents, $71 \%$ were men and $29 \%$ were women. This research was conducted in December $2010^{2}$. Using the results of this questionnaire, a script for an interview was built and applied to an immigrant (man) who was living in Portugal for 15 years. He considered himself very well integrated in Portugal, with his family already settled in the country, operating a family business, children in the school, and all members of the family being independent users of the Portuguese language. The interview focused on his migration trajectory, life history, use of the media in the process of integration in Portugal, learning of Portuguese, and relationship with his family and friends in Nepal and in other parts of the world.

Afterwards, having the questionnaires and this first interview as basis, another script was constructed for the next interviews, which focused on the same matters, but was better

\footnotetext{
${ }^{2}$ Was used on my MA thesis in Portuguese Language and Culture - Teaching Portuguese as a Foreign Language and on my Ph.D thesis in Communication Sciences, which is focused on the Nepalese community in Portugal and on the Portuguese community in Macau - China (Branco, 2012, 2014).
} 
structured. Seven interviews were held, six of which were recorded and one was answered by e-mail. The criteria were the gender and how long has the respondent been living in Portugal. The interviews were conducted with three women and four men, who were living in Portugal for a period between three months and 11 years. The interviews took place in April and May 2011 at the headquarters of the Non-resident Nepalese Association (NRN) and at the workplaces of respondents, and lasted about an hour. They were held in Portuguese or English, depending on the language with which they felt more comfortable.

\section{Results}

The objectives of the application of the 17 questionnaires to a class of Nepalese immigrants who were learning Portuguese at Non Resident Nepalese Association ${ }^{3}$ was to characterize the target-public (class) and to find the motivations to learn the language.

Regarding the characterization: $71 \%$ (12) were men and $29 \%$ (5) were women; the average age was 30 years old, the youngest had 21 and the oldest 40;59\% had higher education, at least with a graduation; 76\% were in Portugal for less than three months.

Among the reasons to choose Portugal to emigrate - they could choose one or more - the two most pointed were "I thought that in Portugal I could have a better life than in Nepal" (53\%) and "It's easier to obtained the residence permit in Portugal than in other European country" $(53 \%)$

Finally, the motivations to learn Portuguese. The most referred (82\%) was "To find a better job". This result is coherent with the most important reason to go to Portugal, this means, to have a better life then in Nepal. This would be possible just if they could find a job and, to find one, they knew that if they speak Portuguese it would be much easier. So, "To speak

\footnotetext{
${ }^{3}$ I was the voluntary teacher.
} 
better" was the second (76\%) most pointed reason to learn Portuguese. Then, came "Read better" and "Communicate at public spaces", both reasons related to basic needs of survival in another country.

53\% mentioned "Read newspapers, watch television, access the Internet", which reflects the need to be informed about the receiving society. This reason and the willingness to have social relationships with Portuguese people, pointed by $35 \%$, reflect a will for integration. More than survival or finding a better job or a better life, they wanted to create social and affective ties with the receiving society.The analysis of the information collected in the interviews is divided into two parts, both related to uses of media by immigrants. The first focuses on adapting to the new society. This part highlights the ways in which my interviewees use media to learn the host language and as a source of information about the receiving culture. The second part concerns the culture of origin, both in terms of connections with family and friends in Nepal as in establishing ties within their own local community.

To maintain the anonymity of each respondent, I chose to use only the initials of their names instead.

\section{Integration into the receiving country}

Regarding integration, the question that immigrants ask themselves is: how should we deal with maintaining our cultural identity and heritage while building relationships between ourselves and others, i.e., our cultural community and local communities? The change in each individual's repertoire of behaviours involves both abandoning some elements of their culture of origin and learning others' cultural elements. This does not happen to everyone in the same way. The degree of original cultural maintenance versus the degree of receiving culture adoption dictates the degree of integration. 
These immigrants, at different times, left Nepal in order to thrive in another country. Although they intend to return one day, the initial goal is to settle down in Portugal. While they struggle to adapt to the country, they seek to maintain their own cultural traits.

On one hand, for example, they seek to adopt some Portuguese habits, like going to the beach; on the other, they try to keep the use of Nepalese language within the community. This way, between one culture and the other, they build a "hybrid identity" composed of elements of both cultures - to do "puja" or to light a candle in a church, praying to Krishna or to Christ, end up being the same.

"For example, we have also Hindu... is Ram and Krishna. Jesus Christ ... is the same. For me it's equal. It's not so rigorous, no. Puja, you know? Like, you go in the church, light candles, it's equal. I do puja, I remember God and that's it! [translated from Portuguese to English]" (S.S.)

Most interviewees left Nepal due to the political instability in the country. The choice of Portugal as a destination country, as founded in the results of the questionnaire, was mainly due to idea that in Portugal is easier to obtain the residence permit than in other European countries. Just after sometime they realize that it's not such a smooth process.

"I thought it was very easy to come here and deal with the documents [residence permit] and go back again [to Germany], because, there, I was earning better. However, when I arrived, I realized it was not, at all, what I expected. It wasn't so fast”. [translated from Portuguese] (T.S.)

Currently, they consider Portugal a place of friendly and honest people, with a good climate and where the Nepalese community is united. The fact that they work long hours and receive a low salary is one of the weaknesses pointed out. Those who have their own business consider that Portuguese employees do not always work as hard as they should: "they are lazy to fulfil their responsibilities [sic]”, S.B. says. 
The economic crisis that Portugal is facing since 2008 is another concern, but the main barrier to integration into the new society is the need to learn the Portuguese language. Also the distance from family and their ignorance about the local culture are factors that hinder adaptation. In this context, Portuguese media presents themselves as accessible and convenient tools of language learning and sources of information about the receiving society.

\section{Learning the receiving country's language}

Language learning is a fundamental part of the instrumental, psychological and cultural adjustment of immigrants to the receiving society (Elias \& Lemish, 2010). Concerning integration in Portugal, learning the Portuguese language proves to be crucial and becomes the first barrier that immigrants face when arriving to the country. Either in day-to-day tasks or in applying for a job, learning the language of the host country is essential. If the immigrants do not learn it, they find themselves locked within their community, being bound to accept jobs for which contact with Portuguese people is not necessary. Thus, among the motivations to learn Portuguese, finding a job emerges as the primary concern.

As discussed above, language, being one of the main pillars of cultural identity, is the most important element to be acquired in the integration process. Given its importance, it can be the main facilitator, when mastered by the immigrants, or the main barrier, if they cannot speak it. Motivation and time are the most important factors that determine the success or failure in learning a language.

Among the eight Nepalese immigrants, five can speak Portuguese and three were learning at the time we did the interview. Of these three, two had arrived in Portugal three months before the interviews and one had been living in Portugal for two years, having basic knowledge of the language. Of those who had learned and could speak, only one immigrant did a formal course. The others learned Portuguese using their own methods and some could speak the 
language reasonably well, while others could speak it very well. The latter was the case of the immigrant who has been living in Portugal for 15 years.

Those immigrants who are in Portugal for a long time and are still in a learning process make use of the (mainstream) Portuguese media for this purpose. Their learning strategies differ depending on the medium used and the length of the stay in Portugal. The most recent immigrants do not buy Portuguese newspapers, preferring to use the Internet to access newspapers websites and to watch Portuguese television channels. They translate content with the help of Portuguese-English dictionaries and online translation tools such as the one provided by Google, "I copy online and translate through Google and I can understand [sic]” Y.C. says.

Another strategy is to watch American movies, spoken in English but subtitled in Portuguese. The use of a medium perceived as belonging to a "global culture", as Hollywood movies (Elias \& Lemish, 2010), but with subtitles in Portuguese, allows them to float between a comfort zone and the new culture. All of them have English skills, even if at a basic level, "We can watch English movie, but in the downside is the write in Portuguese language, I see also Portuguese language and I'm listening English [sic]” S.A. says.

Those immigrants who have been living in Portugal for long periods of time watch Portuguese television channels. As they already have good Portuguese language skills, listening to the language allows them to extend their vocabulary and improve their pronunciation.

"If you'll look at the BBC, it is all in English. While I live in a country, I have to learn the language of the country where I live. If I see Portuguese channels is easier to learn the Portuguese language also [translated from Portuguese to English].” (H.S.)

Information about the receiving country's culture 
The way these immigrants dress is one of the most visible changes, since all of them are dressed according to the Portuguese habits and they do it purposely. This change shows a desire to acquire cultural elements of the destination country. The way a person dresses is a label, a statement of identity. This reveals a strong desire for integration, to participate in the local culture.

However, we cannot conclude that these immigrants deny their own origin culture to affirm cultural values of the destination culture. In the acculturation strategy they adopt - integration - the extent of individual change stems from a desire to adapt, but that does not mean they do not maintain other elements of the culture of origin. We found that they do it, for example, regarding religious practices: they can pray to Krishna but they can also pray to Jesus. They also participate in their own community cultural festivities, and they are proud of it. Another example is what they eat: Nepalese food and also other cultures types of food, not only Portuguese.

Obtaining more information and knowledge about the receiving society is another reason why immigrants use Portuguese media. They watch television shows like contests (ex: portuguese version of "Who wants to be a millionaire) and Portuguese soap operas to try to learn more about the habits of Portuguese people. S.S. has been living in Portugal for eight years and she explained that she only watched Portuguese soap operas because they help her, even then, to understand better Portuguese culture: "Portuguese, Portuguese. Brazilian [soap operas] I never watch. For me are the most important. On television and out there I don't think things are so different [translated from Portuguese to English]"

Even when they don't understand Portuguese, watching this kind of television programs, not only is considered useful for language learning, but also provides them information they consider useful for adaptation to the receiving society, in particular by observing the way 
Portuguese people dress and behave: "I want to learn Portuguese people, how do they talk, how do they dress, everything, so I'm interested [sic]", S.A. says

This interest, in how people of the receiving country dress, is very much relevant in immigrants with different ethnic origins from those of western countries. The dressing style used in the country of origin may or may not be maintained in the receiving country, but this option is not casual. Cultural identity is negotiated and redefined in the new place where they live, even when the ties to the ethnic and religious background are kept. This is a temporary construction, particularly when it finds a new universe, new influences and new habits. These new habits have a relevant effect on the values and customs that immigrants already have, even in the daily routine. The conflict between their home world and the new world of the receiving country is one of the biggest issues faced by immigrants:

"just we think, why we are here? (...) because of family future, that's it, but we cannot lose our culture, I think. You know, now I'm like that [refers to the way she is dressed: jeans and white t-shirt], when I go to Nepal I can change everything, so, we have a culture [sic].” (S.A.)

All interviewees were dressed in "westernized" ways during the interview, and jeans were the most common piece of clothing. Women seem to be those who have to face a larger conflict with this change, because probably they would not always dress this way in their home country, "We can wear like this also [in Nepal], but before, my mother in law, my father in law they don't like that, so... [sic]"'(S.A.).

Established immigrants do not seek much information about the culture in the Portuguese media, but that about the social and political events of the country. We can say that, at this level, they use mainstream media as any Portuguese person would use them.

"Yes, I read them, because I want to know what is happening in the country [Portugal]. Because I'm here, I'm working, I'm living here; I'm also interested in what is happening in the country [translated from Portuguese to English].” (L.P.S.) 


\section{Bridges with the home country}

None of the respondents intended to return to Nepal in the short term. Although everyone had the intention of returning on vacation, they were in Portugal with the intention to work and build a life. Nepal was their homeland to which they intended to go back someday, but only when the political situation became more stable, eventually, to live the last years of their lives.

But to which Nepal do they intend to return? As time goes by, they keep the idea of a homeland that corresponds to the image they have of the day when they left, but that probably no longer exists. Those who have been living in Portugal for a longer period and returned to Nepal on vacation have encountered this reality and realize that the network of professional and social contacts they have in Portugal is now much larger than the one they have in Nepal. If they have their family in the country where they grew up, in Portugal they have their children who may or may not want to return with them to Nepal someday.

Parents and children have been building a "hybrid identity" (Gillespie, 1995; Alvord 2011; Berry 2001). The difference is that parents consider themselves Nepalese people, but their children already speak Portuguese and Nepalese, have Portuguese friends and act according to the habits, for themselves seamlessly familiar, of Portuguese culture.

"Children are like us Nepalese there [in Nepal]. They go to Portuguese school and then come home, sing and speak Portuguese. [translated from Portuguese]” (S.S.)

The greater or lesser ease of access to the country of origin also affects the level of integration achieved by immigrants. In this case, maintaining links with their culture of origin is not so simple, especially because recent immigrants do not have yet the financial ability to travel frequently to Nepal; second, because the state of development and spread of technologies in Nepal, particularly the Internet, is still not enough to allow frequent online 
conversations, as Alvord (2011) mentions in his study about the Nepalese diaspora in the United States of America.

\section{Information about Nepal}

One of the ways they have to maintain these ties is to keep informed about the country. Being aware of news and events in the country of origin is a way to support their "hybrid identities" (Alvord, 2011).

The respondents use online newspapers produced in Nepal: Nepal.com (English and Nepali), nagariknews.com (Nepali), nepalnews.com (English) and onlinekhabar.com (English and Nepali). And transnational media: BBC, CNN and France 24 are the most cited channels. In addition to information about Nepal, they seek information about the world. BBC has a radio service dedicated only to Nepal, bbc.co.uk/nepali, with information in Nepali. None of the immigrants tuned in to this service, preferring to access content through the respective web pages.

\section{Family and friends}

In their homeland these immigrants have family and friends. Global media are used to maintain these ties. Telephone is used as a vehicle of interaction between immigrants and distant family members. In the case of recent immigrants, phone calls sometimes are made daily. Internet, as a vehicle for interaction, is used, especially with family. Immigrants use Email and digital platforms like Skype ${ }^{4}$ with friends. Besides the use of Email, they use social networks. Facebook is the most common, "When I open my Yahoo or Facebook I see so many friends so ... oooh ... I have a history there [sic].” (Y.C.)Community

The Nepalese immigrant community in Portugal seems to be a cohesive group. To stay informed about the events happening in the community, the respondents accessed the

\footnotetext{
${ }^{4}$ www.skype.com/intl/pt/home/
} 
Nepalese sites produced in Portugal, where they found not only information about their community, but also about Nepal and Portugal: sahayatra.com, nepalportugal.com, portonepal.com and ptnepal.com. The advantage, especially for recent immigrants, is the possibility to read news about Portugal written in Nepali.

Another source of information is the association to which they belong, Non-Resident Nepalese Association Portugal, which publishes news and promotes regular meetings where they discuss Nepalese politics, the situation of the Nepalese immigrants in Portugal or the Nepalese diaspora in the world.

This union stated by the Nepalese immigrants in Portugal is, in fact, identified as a factor that distinguishes this community from others in Europe. If on the one hand they have a sense of belonging to a larger community, spread beyond national borders, the "imagined community" (Anderson B. , 1991) on the other hand, their community in Portugal has characteristics that make it unique. The wider Nepalese diaspora in Europe is seen by the interviewees as not so cohesive as the Nepalese community in Portugal, concentrated mainly in the area of Lisbon, well organized and united. For some of these immigrants this is one of the reasons for them to like to live in Portugal.

"Many Nepalis here are very friendly (...). Elsewhere, in many European countries, Belgium, England, there are many Nepalese people, but they have no coordination (...) That's why I like living here [translated from Portuguese to English].” (H. S.)

\section{Uses of media}

Table 2 systematizes the uses of media by the interviewed immigrants. It crosses the type of media - mainstream, ethnic and transnational - with different uses - connection to the culture of origin and connection to the host society. 
Table 2. Uses of media by type of media in the Nepalese community

\begin{tabular}{|c|c|c|c|c|}
\hline \multirow[b]{2}{*}{$\begin{array}{l}\text { Uses of } \\
\text { media }\end{array}$} & \multicolumn{2}{|c|}{ Mainstream } & \multirow[t]{2}{*}{ Transnational } & \multirow{2}{*}{$\begin{array}{c}\text { Ethnic } \\
\text { Produced in the receiving country }\end{array}$} \\
\hline & Produced in the receiving country & Produced in the home country & & \\
\hline \multicolumn{5}{|c|}{ Bridges with the home country } \\
\hline $\begin{array}{r}\text { Family and friends in the } \\
\text { home country and other parts } \\
\text { of the world }\end{array}$ & & & $\begin{array}{l}\text { Telephone and mobile phone. } \\
\text { E-mail, Skype, Facebook. }\end{array}$ & \\
\hline $\begin{array}{r}\text { Information about the home } \\
\text { country }\end{array}$ & & $\begin{array}{l}\text { Nepalese sites produced in Nepal: } \\
\text { ekantipur.com, nagariknews.com, } \\
\text { nepalnews.com, onlinekhabar.com. }\end{array}$ & $\begin{array}{l}\text { BBC, CNN, France 24, BBC Nepal. } \\
\text { All accessed through Internet pages. }\end{array}$ & \\
\hline $\begin{array}{r}\text { Information about the } \\
\text { community }\end{array}$ & & & & $\begin{array}{l}\text { Nepalese sites produced in Portugal: } \\
\text { sahayatra.com, nepalportugal.com, } \\
\text { portonepal.com, ptnepal.com. }\end{array}$ \\
\hline \multicolumn{5}{|c|}{ Integration into the receiving society } \\
\hline $\begin{array}{l}\text { Information about the } \\
\text { receiving society }\end{array}$ & $\begin{array}{l}\text { All immigrants: } \\
\text { Portuguese national TV channels } \\
\text { (RTP1, RTP2, SIC and TVI): } \\
\text { portuguese soap operas and contests. } \\
\text { Established immigrants: } \\
\text { National distribution newspapers } \\
\text { (Público, Correio da Manhã, Diário de } \\
\text { Notícias and Expresso); free newspaper } \\
\text { distributed in Lisbon (Metro); and } \\
\text { weekly magazines (Sábado and Visão } \\
\text { accessed through Internet sites). } \\
\text { National news broadcasted in the } \\
\text { Portuguese national TV channels. }\end{array}$ & & & $\begin{array}{l}\text { Nepalese sites produced in Portugal: } \\
\text { sahayatra.com, nepalportugal.com, } \\
\text { portonepal.com, ptnepal.com: } \\
\text { information about Portugal, mainly } \\
\text { about Portuguese institutions and } \\
\text { relevant subjects for immigrants. }\end{array}$ \\
\hline
\end{tabular}


Table 2. Uses of media by type of media in the Nepalese community (cont.)

\begin{tabular}{|c|c|c|c|c|}
\hline \multirow[b]{2}{*}{$\begin{array}{l}\text { Uses of } \\
\text { media }\end{array}$} & \multicolumn{2}{|c|}{ Mainstream } & \multirow[t]{2}{*}{ Transnational } & \multirow{2}{*}{$\begin{array}{l}\text { Ethnic } \\
\text { Produced in the receiving country }\end{array}$} \\
\hline & Produced in the receiving country & Produced in the home country & & \\
\hline \multicolumn{5}{|c|}{ Integration into the receiving society } \\
\hline $\begin{array}{r}\text { Information about the rest of } \\
\text { the world }\end{array}$ & $\begin{array}{l}\text { Established immigrants: } \\
\text { National distribution newspapers } \\
\text { (Público, Correio da Manhã, Diário de } \\
\text { Notícias and Expresso); free newspaper } \\
\text { distributed in Lisbon (Metro); and } \\
\text { weekly magazines (Sábado and Visão } \\
\text { accessed through Internet sites). } \\
\text { Portuguese national TV channels } \\
\text { (RTP1, RTP2, SIC and TVI) }\end{array}$ & & $\begin{array}{l}\text { BBC, CNN, France } 24, \text { BBC Nepal. } \\
\text { All accessed through Internet pages. }\end{array}$ & \\
\hline $\begin{array}{r}\text { Aprendizagem da língua de } \\
\text { acolhimento }\end{array}$ & $\begin{array}{l}\text { Recent immigrants: } \\
\text { Internet pages of Portuguese } \\
\text { newspapers. } \\
\text { Established immigrants: } \\
\text { National TV channels }\end{array}$ & & $\begin{array}{l}\text { North american movies with } \\
\text { subtitles in Portuguese language }\end{array}$ & \\
\hline
\end{tabular}




\section{Conclusion}

\section{Culture of the home country}

The necessary transition, the behavior changes in the repertoire of each one - involving both the abandonment of some elements of their culture as the learning of other elements - does not happen to everyone equally. Some are taken at will of each individual; others are necessary to adapt to the new society and, as such, the individual has to take them to integrate; other changes happen imperceptibly along the length of stay in the receiving society. The degree of cultural maintenance vs the incorporation of cultural elements of the receiving society dictates the degree of integration. In this context, the greater or lesser ease of access to the country of origin also affects the level of integration achieved.

For the immigrants focused on this research, maintaining ties with their culture of origin is not as accessible. Particularly the more recent immigrants didn't yet built a financial base that allows them to have capacity to frequently travel to Nepal. Also, the state of development and spread of technologies in this country, particularly the Internet, is still not enough to allow so easy contacts. As Alvord (2011) refers, the differences in terms of access and infrastructure have consequences. Nepal existing infrastructure is not the same that exists in more technologically developed countries such as the United States and Portugal, and may hinder contact with family and friends, making the process slower. Even for those who have family in metropolitan areas like Kathmandu, although they have stated that the same possibilities that exist in Portugal exist also in Nepal, the price of the service, delays and unreliable electricity continue to hinder communication. These limitations affect the psychological and emotional ties in relation to the home country.

One of the ways they have to maintain these ties, even with the difficulty of communication with family and friends in Nepal, is to stay informed about the country. As also found Alvord (2011) in his study, being informed about news and events occurring in the country of origin 
is a way to support the immigrants' hybrid identities. For this purpose the immigrants in this research used online newspapers produced in Nepal and transnational media.

\section{Culture of the receiving country}

Regarding the participation in the receiving society, in the acculturation strategy they adopt integration - the extent of individual change is the result of a natural desire to adapt, but does not mean that they don't keep other elements of the culture of origin, like religious practices, eating and the other habits of everyday life, which can be kept only within the community or not.

\section{Cultural community in the receiving society}

The feeling that immigrants nourish for their own community, the way they see it and how they seek to stay informed about it contribute to the desire to maintain ties with the cultural community within the receiving society. The general feeling noticed in the among the interviees is that it is a cohesive group, where they help each other. Thus, they see in the community a safe place from where they leave to interact with the wider society and where they can return for comfort.

\section{Receiving society}

The wish to affirm the cultural traits of the receiving society is closely related to the valorization of the habits and customs of it. Thus the way immigrants see the receiving society - which in this case happens to be the "other" - is also important in the strategy of integration.

The Nepalese interviwees in general, but especially the members who live for a longer time in Portugal, appreciate living in Portugal and see the Portuguese people as affable and honest people. All Nepalese immigrants in focus expressed interest in being informed about the 
wider society, both regarding the habits and customs and the information about what happens in the country.

\section{Language of the receiving country}

The language of the receiving society is one of the main pillars of its cultural identity and consequently on of the most important elements to be acquired in the integration process. Among the eight Nepalese immigrants interviewed, five could speak Portuguese and three were learning at the time. The main motivation for learning the language has proved to be the desire to find a job.

Upon the arrival in Portugal, these immigrants had little information about the country. In addition, many arrived with tourist visas and needed to rectify the situation. For such, a labor contract is crucial and not knowing Portuguese worsens their situation. Then they begin to learn the language, but in the meanwhile the community support is crucial, because without knowing Portuguese is within it they seek for a job. From my observation made in the community the Nepalese businesses employ other Nepalese people. Finally, when they find a job, they no longer have time to attend courses, since the restaurants schedule do not coincide with the courses schedule. In this way, they end up closed within the community, working for other members and do not have enough knowledge of Portuguese to create social relationships with Portuguese while they show the desire to do so. It may be said that, in their case, the possession of linguistic capital (Bourdieu 1991) is crucial.

We found that the Nepalese immigrants who reside in Portugal for a longer time are the ones who have economically prospered the most; this is one factor that is directly correlated to the other. As they acquire a better financial situation, they have no reason to leave the country that allows them to achieve this prosperity, which is related to the knowledge of the Portuguese language. Knowing the language allows them to evolve in their businesses by facilitating, for example, the relationship with Portuguese customers and suppliers; 
simultaneously the desire to improve their social relationships, and consequently the success of their companies, acts as a strong motivation for learning the language.

As they realize that linguistic capital can be transformed into social and economic capital (Bourdieu, 1991), these immigrants facilitate the access to language learning to their employees who are recent Nepalese immigrants. For example, they hire private Portuguese tutors to teach Portuguese to employees whose job requires contact with customers. They distribute this linguistic capital to the rest of the community through a cascade effect. Alongside with the situation in Nepal, this possibility of flourishing in Portugal, due in part to this intra-community support, is believed to be one of the reasons for the growth of the Nepalese community since 2006.

\section{Uses of media in the integration process}

The audience made up of immigrants divide their attention between the ethnic, mainstream and transnational media. They depend on transnational media to share their sense of identity, but the local and national contexts in which they live, where ethnic and mainstream media are found, are equally important to the identity construction of these communities (Georgiou, 2005).

\section{Ethinc and mainstream media}

Wood \& King (2001), consider that ethnic media can either help immigrants feel at home in their destination countries - serving as a means of learning about the new society and the ways how they can adapt to it - and can help slow their process of integration by promoting the closing of immigrants within their community. That is, the conclusions depend on other factors.

As explained by Carvalheiro (2008), the use of media should not be seen as consumption in the strict sense, but also as practice. So just asking "what" products are consumed it's not 
enough, it is also necessary to consider "how" they are consumed. Ignoring the articulation of media with other factors results in a "mediacentrism" fatal to the understanding of ethnic identities. In this study I sought to know not only which media immigrants use and how. I also sought to know their migratory routes, how their integration is processed their connection to the cultures of origin and destination and the importance of the host language.

The idea that ethnic media are perpetrators of identity differences and that mainstream media are integrators wasn't observed in this research. The reasons for this conclusion are due primarily to the fact that the receiving society adopts a multicultural and non-assimilationist strategy; secondly, because the use of the media is conditioned by the knowledge of the language of the receiving country.

Ethnic media are used to obtain information about the country of origin, but especially to find information in Nepali (mother tongue) about the receiving society, which reveals a sense of integration and not separation or closure.

Regarding mainstream media, the interviewees use mainly the television channels of open signal and the daily newspapers of national distribution. The way they use them is conditioned by the knowledge that immigrants already have of Portuguese language. Those who do not yet have reasonable knowledge of the language watch, for example, television contests and observe the way Portuguese competitors dress and the behave. Those with more knowledge of the language, also watch contests and Portuguese soapoperas, where in addition to gestures, manner of dressing and other cultural habits, they seek to improve the knowledge of the language. In addition, they look for information about Portugal, which suggests an interest in the receiving culture.

\section{Transnational media}


Transnational media are used in maintaining ties with the country of origin. With a format of one to one or many to many, they are used to contact family and friends, whether they are in their home country or in another country. The search for news about other countries and the search for employment opportunities in the rest of the world through social networks like Facebook, make the experiences of transnationalism go beyond the barriers of the country of origin and the receiving country.

\section{References}

Alvord, D. (2011). Strangers in a globalized world: identity and assimilation among korean and nepalese immigrants. Thesis submitted in partial fulfillment of the requirements for the degree of Master of Arts in the Department of Sociology and Social Work. University of Central Missouri.

Anderson, B. (1991). Comunidades imaginadas: reflexões sobre a origem e a expansão do nacionalismo. Lisboa: Edições 70.

Berry, J. W. (2001). A Psychology of Immigration. Journal of Social Issues, 57, pp. 615-631.

Berry, J. W. (2008). Globalisation and Aculturation. International journal of intercultural relations, 32, pp. 328-226.

Berry, J. W., \& Sam, D. (2006). Contexts of acculturation. In S. \&. Berry, Theories, Concepts and Methods (pp. 27-42).

Bourdieu, P. (1991). Language \& symbolic power. (J. Thompson, Ed.) Cambridge, Massachusetts: Harvard University Press. 
Branco, I. (2012). A importância da língua de acolhimento na integração de imigrantes nepaleses em Portugal. MA thesis in Portuguese Language and Culture - Teaching Portuguese as a Foreign/Second Language. Lisbon: University of Lisbon.

Branco, I. (2012, December). A língua portuguesa e os média na integração de imigrantes nepaleses em Portugal. Anuário Internacional de Comunicação Lusófona 2012 : Médios Públicos e Espazo Lusófono. Coordination Lusocom / Agacom. ISSN 18079474, pp. 133-147.

Branco, I. (2012, December). A língua portuguesa e os média nas vivências de imigrantes nepaleses em Portugal. Comunicando: Os Novos Caminhos da Comunicação. Coordination SOPCOM. ISSN 2182-4037, pp. 66-89.

Branco, I. (2014, December). A investigação sobre média e imigração em Portugal. Anuário Internacional de Comunicação Lusófona. Coordination Lusocom / Agacom. ISSN 2255-2243, pp. 153-169.

Burrell, J., \& Anderson, K. (2008, Março). 'I have great desires to look beyond my world': trajectories of information and communication technology use among Ghanaians living abroad. New Media \& Society, pp. 203-224.

Carvalheiro, J. R. (2008). Do Bidonville ao Arrastão: Média, Minorias e Etnicização. Lisboa: Instituto de Ciências Sociais.

Elias, N. (2011, January). Between Russianness, Jewishness, and Israeliness: Identity Patterns and Media Uses of the FSU Immigrants in Israel. Journal of Jewish Identities.

Elias, N., \& Lemish, D. (2006). Between three cultures: media in the lives of immigrant children in Israel and Germany. Paper submetido na Instructional and Development Division da conferência anual da International Communication Association. Dresden. 
Elias, N., \& Lemish, D. (2008). Media uses in immigrant families: torn between "inward" and "outward" paths of integration. International Communication Gazette, 70, pp. 23-42.

Elias, N., \& Lemish, D. (2008). Media uses in immigrant families: torn between "inward" and "outward" paths of integration. International Communication Gazette, 70, pp. 23-42.

Elias, N., \& Lemish, D. (2010). Media, migration experience and adolescence. Televizion.

Elias, N., \& Lemish, D. (2011, March 14). Between three worlds: host, homeland and global media in the lives of russian immigrant families in Israel and Germany. Journal of Family Issues.

Georgiou, M. (2005). Diasporic Media Across Europe: Multicultural Societies and the Universalism-Particularism Continuum. Journal of Ethnic and Migration Studies, pp. 481-498.

Giddens, A. (2007). Sociologia. Lisboa: Fundação Calouste Gulbenkian.

Katz, E., \& Blumler, J. G. (1974). The uses of mass communication. Newbury Park.

Livingstone, S. (1997). The work of Elihu Katz: conceptualizing media effects in context. International media research: a critical survey, pp. 18-47.

Maalouf, A. (1998). As Identidades Assassinas. Lisboa: Difel.

Pareck, B. (2000). Rethinking Multiculturalism: Cultural Diversity and Political Theory. Londres: Macmillan Press.

Pires, R. P., Machado, F. L., Peixoto, J., \& Vaz, M. J. (2010). Portugal: Atlas das Migrações Mundiais. Lisboa: Fundação Calouste Gulbenkian, Comissão Nacional para as Comemorações do Centenário da República e Edições tinta-da-china, Lda. 
Reece, D., \& Palmgreen, P. (2000). Coming to America: need for acculturation and media use motives among indian sojourners in the US. International Journal of Intercultural Relations, 24, pp. 807-824.

SEFSTAT, P. d. (2014). População Estrangeira Residente em Território Nacional, por destrito e por nacionalidade, em 2013. Lisboa: SEF.

Silverstone, R., \& Georgiou, M. (2005). Editorial Introduction: Media and Minorities in Multicultural Europe. Journal of Ethnic and Migration Studies, pp. 433-441.

Wood, N., \& King, R. (2001). "Media and Migration. An overview", in Wood, Nancy e King, Russell (orgs.) "Media and Migration. Constructions of mobility and difference". London: Routledge.

Young, J. (1999). The exclusive society. London: Sage. 